\title{
Using Air Pressure Cells to Evaluate the Effect of Soil Environment on the Transmission of Soilborne Viruses of Wheat
}

\author{
L. Cadle-Davidson, R. R. Schindelbeck, H. M. van Es, S. M. Gray, and G. C. Bergstrom
}

First and fifth authors: Department of Plant Pathology; second and third authors: Department of Crop and Soil Sciences; and fourth author: U.S. Department of Agriculture-Agricultural Research Service, Plant Protection Research Unit, Cornell University, Ithaca, NY 14853. Accepted for publication 31 March 2003.

\begin{abstract}
Cadle-Davidson, L., Schindelbeck, R. R., van Es, H. M., Gray, S. M., and Bergstrom, G. C. 2003. Using air pressure cells to evaluate the effect of soil environment on the transmission of soilborne viruses of wheat. Phytopathology 93:1131-1136.

An air pressure cell, a laboratory tool that precisely controls soil matric potential, was utilized in a novel approach to investigate the epidemiology and management of soilborne disease. Matric potentials of -1 , $-5,-20$, and $-40 \mathrm{kPa}$ were established in cores of field soil infested with Wheat soilborne mosaic virus (WSBMV) and its presumed vector Polymyxa graminis. Equilibrated soil cores were planted to wheat (Triticum aestivum), and after intervals of growth under controlled environment, virus transmission was assessed by serological detection of the virus in washed roots. Transmission occurred at all but the driest soil

graminis zoospores. By starting plants at $-40 \mathrm{kPa}$ for 10.5 days and then watering them to conducive matric potential, we found that WSBMV transmission occurred between 12 to $24 \mathrm{~h}$ at $15^{\circ} \mathrm{C}$, and within $36 \mathrm{~h}$ at $20^{\circ} \mathrm{C}$. No significant transmission occurred within $96 \mathrm{~h}$ at $6.5^{\circ} \mathrm{C}$. In contrast, transmission of Wheat spindle streak mosaic virus (WSSMV) did not occur at $15^{\circ} \mathrm{C}$ (the only transmission temperature tested), suggesting either that WSSMV is unable to establish infection at $15^{\circ} \mathrm{C}$ or that a different vector is involved. The air pressure cell is a novel tool with many potential applications in research on the epidemiology and management of soilborne pathogens. Applications of the precise environmental control attained through the use of air pressure cells range from assessing the effects of cultural practices on soilborne inoculum to standardized virulence assays for soilborne pathogens to preliminary screens of host resistance and pesticide efficacy.
\end{abstract} matric potential tested, $-40 \mathrm{kPa}$, in which only pores with a diameter of $7.4 \mu \mathrm{m}$ or less were water-filled, possibly obstructing movement of $P$.
Additional keywords: Bymovirus, Furovirus, soil ecology, soil microbiology.
Over 30 soilborne viruses are known to cause economically significant diseases in both monocot and dicot production systems worldwide $(1,6)$. Zoospores of the plasmodiophorid Polymyxa graminis Ledingham are presumed to transmit at least a dozen viruses including Wheat soilborne mosaic virus (WSBMV) and Wheat spindle streak mosaic virus (WSSMV), both of which cause yield-limiting diseases of winter cereals worldwide $(9,12$, 19). Symptoms of WSBMV and WSSMV usually occur in the spring on autumn-planted wheat and rarely are seen in the autumn (4). We have observed that planting dates as few as 3 days apart in the autumn can result in significantly different incidence of viral symptoms in the spring (L. Cadle-Davidson and G. C. Bergstrom, unpublished data). This suggests a relatively narrow window for significant transmission to occur, presumably defined by the soil environment soon after planting.

$P$. graminis resting spores and internally borne viruses can survive for as long as 10 years in soil (1). Under proper environmental conditions after planting of a susceptible host, a resting spore germinates to form a single swimming zoospore that encysts on the host root and infects a root cortical cell (17). Zoospore contents (including the infectious virus) are transferred into the root cortical cell by a stachel-mediated mechanism similar to that described for Plasmodiophora brassicae (3).

Temperature and soil matric potential have been discussed as important environmental parameters for $P$. graminis infection and

Corresponding author: G. C. Bergstrom; E-mail address: gcb3@ cornell.edu

Publication no. P-2003-0721-01R

This article is in the public domain and not copyrightable. It may be freely reprinted with customary crediting of the source. The American Phytopathological Society, 2003. viral transmission. Furthermore, cool temperatures seem to be required for replication, systemic infection, and symptom expression of WSBMV and WSSMV $\left(8\right.$ to $20^{\circ} \mathrm{C}$ and 5 to $15^{\circ} \mathrm{C}$, respectively) $(5,21)$. Slykhuis (22) showed that WSSMV transmission can occur within 16 days at temperatures ranging from 7.5 to $17.5^{\circ} \mathrm{C}$, with up to $50 \%$ infection at $15^{\circ} \mathrm{C}$. Thermoperiodism between 5 to $15^{\circ} \mathrm{C}$ (night-day), however, resulted in WSSMV transmission of up to $96 \%$. In studies using suspensions of zoospores to infect barley (Hordeum vulgare), Adams and Swaby (2) showed that $P$. graminis required $3 \mathrm{~h}$ at $15^{\circ} \mathrm{C}$ for attachment and host penetration to occur. Brakke et al. (5) showed that WSBMV transmission from zoospore suspensions can occur within $24 \mathrm{~h}$ at temperatures ranging from 5 to $25^{\circ} \mathrm{C}$, but no studies have used field soil for determining optimal WSBMV transmission temperatures.

Soil moisture also is a critical factor for soilborne virus transmission by swimming zoospores. Soil matric potential (measured in kilopascals) reflects how tightly water is being held as a result of adhesive (soil-water) and cohesive (water-water) forces or how much energy is required to empty the pore. As soil dries and the soil matric potential decreases (becomes more negative), increasingly smaller pores are being emptied (14). When the soil matric potential decreases from -5 to $-20 \mathrm{kPa}$, for instance, the largest water-filled pore size shifts from a diameter of 55.9 to $14.7 \mu \mathrm{m}$. There have been few quantitative studies on how soil matric potential affects soilborne virus transmission. Himmel et al. (11) used hanging water columns with fritted filters to show that at $16^{\circ} \mathrm{C}\left( \pm 5^{\circ} \mathrm{C}\right)$ a soil matric potential of $-20.5 \mathrm{kPa}$ was significantly less conducive for WSBMV transmission to wheat than a soil matric potential of $-13.0 \mathrm{kPa}$. However, the plant water demand exceeded the ability of the fritted filter apparatus to maintain the desired matric potentials, resulting in a less precise estimation of optimal transmission conditions. 
Although field incidence of either WSSMV or WSBMV often reaches 80 to $100 \%$, growth chamber studies using WSBMVinfested field soil typically obtain 20 to $40 \%$ transmission under the most conducive conditions $(10,11,16)$. Considering how little is known about the biology and epidemiology of soilborne virus transmission and the difficulty in achieving high infection rates in controlled environments, a precise technology is needed to dissect soilborne virus pathosystems.

The purpose of this study was to determine the soil water conditions, temperature, and duration required for efficient WSBMV

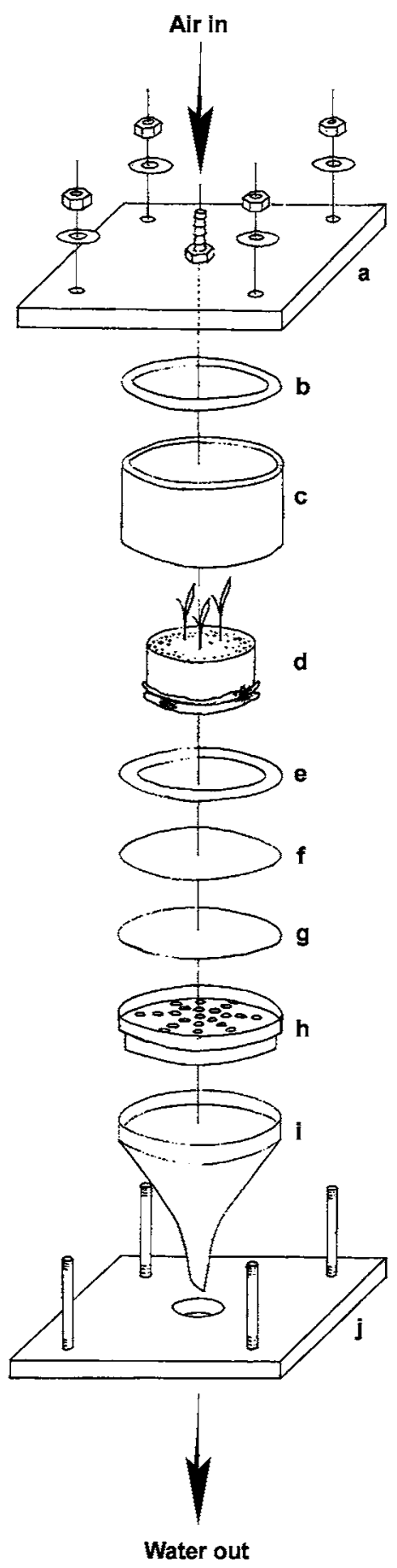

Fig. 1. Schematic of air pressure apparatus: a, plexiglass top, fastened with hexagonal nuts to bolts from the base; b, rubber ring; c, PVC pipe; d, soil core; e, rubber ring; $\mathrm{f}$ and $\mathrm{g}$, nylon membranes, $0.45 \mu \mathrm{m}$ pore size (Osmonics, Minnetonka, MN); h, plastic tray with 3-mm drainage holes; i, plastic funnel; and j, base with bolts attached. Line drawing by J. Cianchetti, Department of Plant Pathology, Cornell University, Ithaca, NY. transmission. We utilized a novel laboratory-based technique for precise environmental control.

\section{MATERIALS AND METHODS}

Soil core preparation and equilibration. Conesus gravelly silt loam soil was collected from a WSBMV evaluation nursery in Trumansburg, NY. Williamson very fine sandy loam soil was collected from a WSSMV evaluation nursery in Ithaca, NY. Soil was screened through a sieve with 2-mm openings, air dried, and then thoroughly mixed. Soil cores $(10-\mathrm{cm}$ diameter by $7.5 \mathrm{~cm}$ tall) were prepared by attaching two layers of cheesecloth to the bottom of a metal ring with a rubber band, adding approximately $550 \mathrm{~g}$ of dry soil followed by approximately 50 seeds, and covering with $100 \mathrm{~g}$ of dry soil. Exact weight of the dry soil cores was recorded. Susceptible wheat cvs. Harus and Pioneer 2548 were planted for the WSBMV and WSSMV experiments, respectively. Sieved, repacked soil cores were then slowly saturated in tubs of water for 2 days. Because wheat seeds do not germinate in the dry soil cores, the beginning of saturation is the reference point by which we determine the days after planting. After the second day of saturation, soil cores were transferred to the air pressure cell apparatus (Fig. 1). Soil matric potential treatments were established by equilibrating for 2 days. The soil sample reaches equilibrium when all pores that cannot hold water against the applied pressure have been emptied. Following equilibration, soil cores were weighed and placed on 150-mm disposable petri dish lids. At this point (4 days after planting), seedlings began emerging and roots were presumably available for infection.

Each soil type releases water in a characteristic manner as the soil matric potential decreases, a behavior related to the soil pore size distribution and commonly depicted in soil water release curves. Six sieved, repacked cores per site were used to determine the soil water release curves (Fig. 2) by equilibrating at eight sequential soil matric potentials $(-0.1,-0.375,-1.4,-2.4,-5.4$, $-10.4,-20.4$, and $-40.4 \mathrm{kPa}$ ) in air pressure cells for 2 days each and calculating the volumetric water content based on the bulk density and the water released at each pressure $(13,14)$. Seeds were not planted in the cores used for calculating soil water release curves.

Identifying conducive soil matric potentials for WSBMV and WSSMV transmission. Equilibrated soil cores were removed from the air pressure cells and placed in a growth chamber at $15^{\circ} \mathrm{C}\left( \pm 1^{\circ} \mathrm{C}\right)$ in an 8 -h light/16-h dark regime $\left(120 \mu \mathrm{E} \mathrm{m}^{-2} \mathrm{~s}^{-1}\right.$ at soil level). At 9 days after planting, seedlings were thinned to 20 per core. Soil cores were hand watered from the top of the core to equilibrium weight once every $24 \mathrm{~h}$ to maintain soil matric potential with compensation being made for plant growth. At 14, 21 , and 28 days after planting, cores were destructively sampled to determine WSBMV transmission efficiency. At 26 days after planting, cores were destructively sampled for WSSMV transmission evaluation. Individual plants were separated and roots were washed free of soil. Sap was extracted from roots of individual plants with a rolling leaf press and diluted in $0.5 \mathrm{ml}$ of phosphatebuffered saline. Enzyme-linked immunosorbent assay (ELISA) was used to detect WSBMV according to the manufacturer's instructions (Agdia, Elkhart, IN) or to detect WSSMV (8). Percent transmission was calculated as the number of plants infected over the number of plants grown in the infested soil core. Cores were randomized among treatments and in the growth chamber, and each experiment was repeated four times. The difference in transmission efficiency between treatments was analyzed using Proc Logistic in SAS (SAS Institute, Cary, NC). Proc Logistic creates a statistic known as the odds ratio, which is simply the ratio of the odds of infection for one treatment versus the odds of infection for another treatment (e.g., the negative control).

Based on the results of the WSSMV experiment, we repeated the experiment with the following modifications. At 21 days after 
planting, roots were washed free of soil, soaked for $5 \mathrm{~min}$ in $2.5 \mathrm{mM} \mathrm{ZnSO}_{4}$, and transplanted in vermiculite. These plants were then placed, in a completely randomized design, in a growth chamber at 4 or $12^{\circ} \mathrm{C}$ for 17 days or at $12^{\circ} \mathrm{C}$ for 90 days to allow for viral replication.

Time required for WSBMV transmission at conducive soil matric potential. For this component of the study, four replicate soil cores per treatment were equilibrated to $-40 \mathrm{kPa}$ and placed in a growth chamber at $15^{\circ} \mathrm{C}\left( \pm 1^{\circ} \mathrm{C}\right)$ in an 8-h light/16-h dark regime $\left(120 \mu \mathrm{E} \mathrm{m} \mathrm{m}^{-2} \mathrm{~s}^{-1}\right.$ at soil level) for 4 days followed by $20^{\circ} \mathrm{C}$ for 2 days. During this time, soil cores were hand watered to $-40 \mathrm{kPa}$ equilibrium weight once every $24 \mathrm{~h}$. Cores were then distributed to four temperature treatments $\left(6.5,10,15\right.$, and $\left.20^{\circ} \mathrm{C}\right)$ in dark growth chambers and equilibrated for $12 \mathrm{~h}$. Following temperature equilibration, cores were watered from the top of the core to a soil matric potential (between -1 and $-5 \mathrm{kPa}$ ) conducive for virus transmission and kept in the dark at the treatment temperatures for $4,12,24,36,48$, or 96 h. Negative controls were maintained in the dark at the treatment temperatures for 48 or $96 \mathrm{~h}$ at $-40 \mathrm{kPa}$. Cores were kept in the dark to negate variation in light intensity in the four chambers used. After the treatment period, roots were washed free of soil, soaked for $5 \mathrm{~min}$ in $2.5 \mathrm{mM} \mathrm{ZnSO}_{4}(163 \mu \mathrm{g}$ of $\mathrm{Zn}$ per $\mathrm{ml})$ to prevent further $P$. graminis infection $(2,23)$, and transplanted in sterile vermiculite. Transplants were maintained in a growth chamber at $15^{\circ} \mathrm{C}$ under half-intensity fluorescent lighting until 22 days after initiation of the experiment in order to allow equitable viral replication across treatments. Individual plants were tested for WSBMV transmission, and data were analyzed as described previously, except treatment replicates had been pooled at transplanting. A total of 182 negative control plants representing all treatment temperatures were pooled for analysis and comparison.

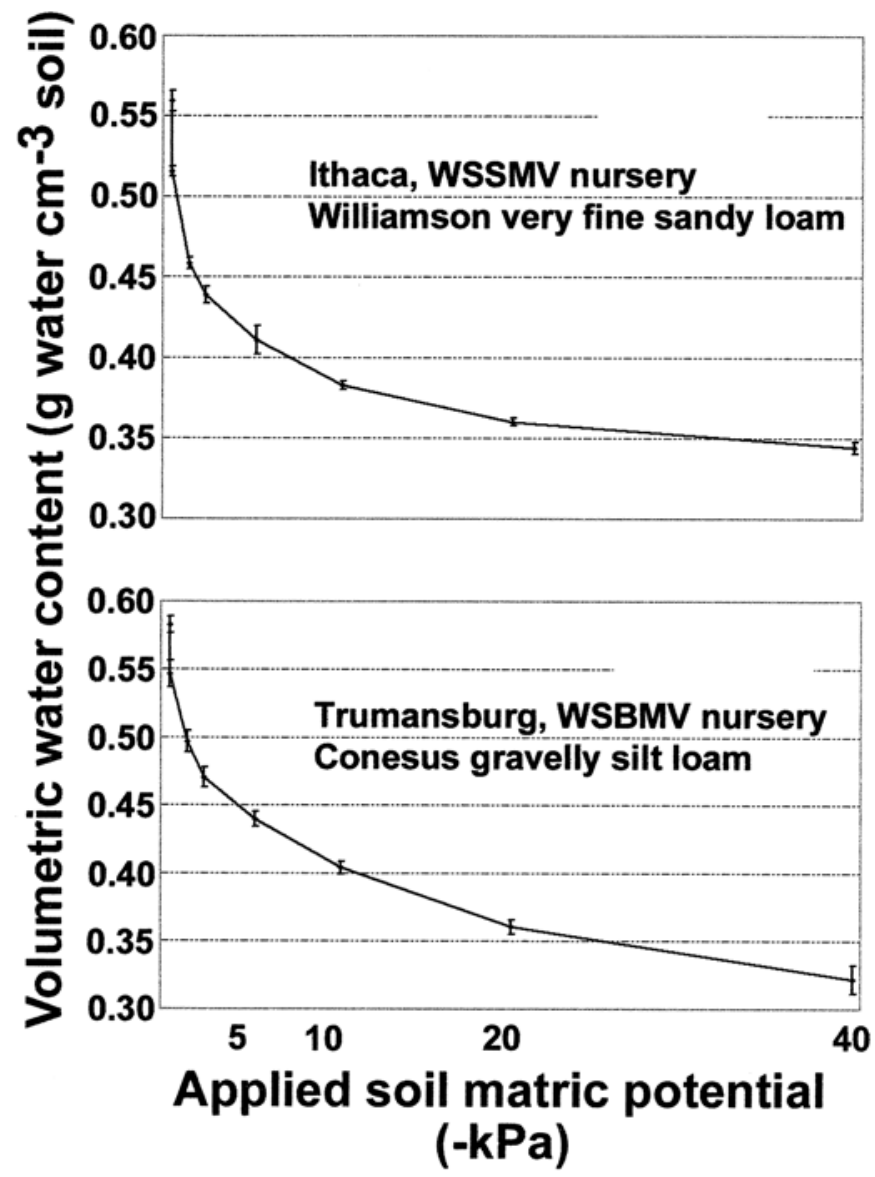

Fig. 2. Soil water release curve for sieved, repacked soil cores. Each data point represents an average of six cores. Error bars represent standard deviation.
This experiment was repeated in order to verify the results and to better understand transmission response between 6.5 and $10^{\circ} \mathrm{C}$, a relevant soil temperature range after autumn planting. The experiment was conducted as described previously with the following exceptions. The temperature treatments were $6.5,8$, and $10^{\circ} \mathrm{C}$. The time points were $0,12,36$, and $96 \mathrm{~h}$. These were selected based on the relevant findings from the preceding experiment and were initiated at 15 days after initiation of the experiment. The treatments were initiated by slow saturation from below in tubs of water. Transplants were maintained until 32 days after initiation of the experiment, and replicates were not pooled.

\section{RESULTS}

Soil matric potential maintenance. The low light conditions and daily hand watering allowed maintenance of matric potential treatments throughout the experiment, as the driest that any core became between daily watering events was always wetter than the next drier treatment (Fig. 3). Thus, the true matric potential treatment was somewhere between the maximum and minimum moisture for each day. When sampled at 14, 21, and 28 days after planting, the 10 plants per core averaged 2,3 , and $4 \mathrm{~g}$, respectively. This weight was accounted for in subsequent watering. Plants grew equally well at all soil matric potentials tested.

Identifying conducive soil matric potentials for WSBMV and WSSMV transmission. The soil matric potential and the number of days maintained under a given soil matric potential were both highly significant predictors of WSBMV transmission (Table 1$)$. The three wettest soil matric potentials tested $(-1,-5$,

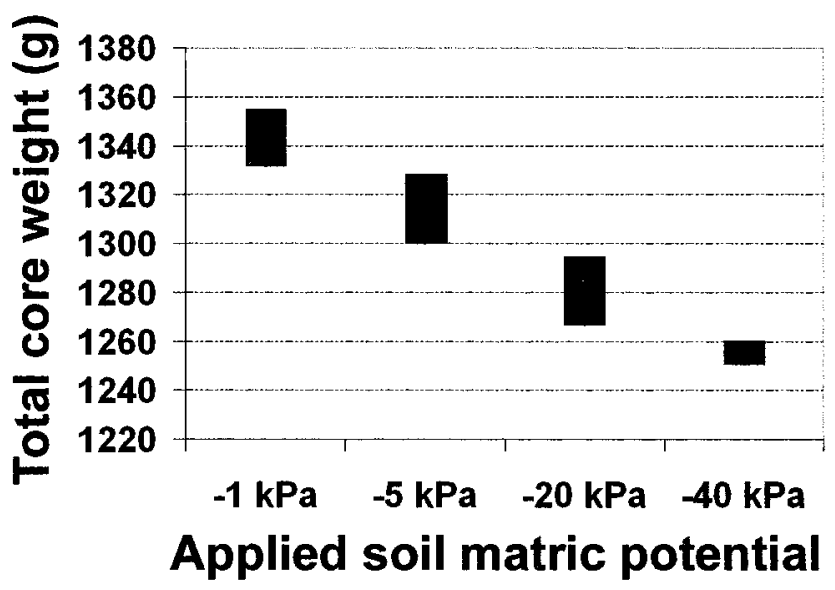

Fig. 3. Average total core weight and daily fluctuation for each matric potential. The maximum value for a bar represents the average total core weight for the treatment listed at equilibrium and immediately following watering. The minimum value for a bar represents the average total core weight immediately prior to watering.

TABLE 1. Analysis of maximum likelihood estimates (MLEs) for identifying conducive soil matric potentials for Wheat soilborne mosaic virus transmission $^{\mathrm{a}}$

\begin{tabular}{lcrrrr}
\hline Parameter & df & \multicolumn{1}{c}{ MLE } & SE & Wald $\chi^{2 \mathrm{~b}}$ & $P$ value \\
\hline Intercept & 1 & 0.9336 & 0.5146 & 3.2920 & 0.0696 \\
Kilopascals $^{\mathrm{c}}$ & 1 & -0.1164 & 0.0093 & 155.0726 & $<0.0001$ \\
Day $^{\mathrm{d}}$ & 1 & 0.1058 & 0.0246 & 18.4334 & $<0.0001$ \\
\hline
\end{tabular}

a This table is derived from the output of Proc Logistic in SAS (SAS Institute, Cary, NC) with both kilopascals and day as random variables. The interaction term kilopascals-day was nonsignificant at $\alpha=0.10$ and therefore dropped from the model.

b The Wald chi-square test statistic is a likelihood-ratio statistic of the null hypothesis that the parameter for the given predictor is zero. This has an asymptotic $\chi^{2}$ distribution.

Soil matric potential.

d Number of days between planting and harvesting. 
and $-20 \mathrm{kPa}$ ) were all significantly more conducive for WSBMV transmission $(P<0.0001)$ than the driest soil matric potential $(-40 \mathrm{kPa})$ at all time intervals tested (Fig. 4). The wettest treatment $(-1 \mathrm{kPa})$ was the most conducive at all sampling dates and was significantly more conducive than the second wettest $(-5 \mathrm{kPa})$ at 21 days after planting. The longer that plants were incubated, the higher the transmission efficiency. At 28 days after planting, nearly every plant in the three conducive treatments tested positive for WSBMV.

At 26 days after planting, 17 plants from each of four replicate cores of each matric potential $(-1,-5,-20$, and $-40 \mathrm{kPa})$ were tested for WSSMV transmission. No plant from any treatment tested positive for WSSMV (data not shown). We hypothesized that $15^{\circ} \mathrm{C}$ was not favorable for WSSMV replication after $P$. graminis infection and viral transmission, and correspondingly, we made minor adjustments and repeated the experiment. From the pool of 203 plants maintained at 4 and $12^{\circ} \mathrm{C}$ for 17 days following the matric potential treatments, no plant tested positive for WSSMV capsid protein (data not shown). From the pool of 190 plants maintained at $12^{\circ} \mathrm{C}$ for 90 days, only one plant tested positive for WSSMV capsid protein. This plant was 1 of 41 plants from the $-5-\mathrm{kPa}$ treatment (data not shown).

Time required for WSBMV transmission at conducive soil matric potentials. We established and maintained nonconducive soil matric potentials $(-40 \mathrm{kPa})$ in all soil cores until 10.5 days after planting, at which time the temperature and time treatments were initiated under conducive matric potentials. Both the tem-

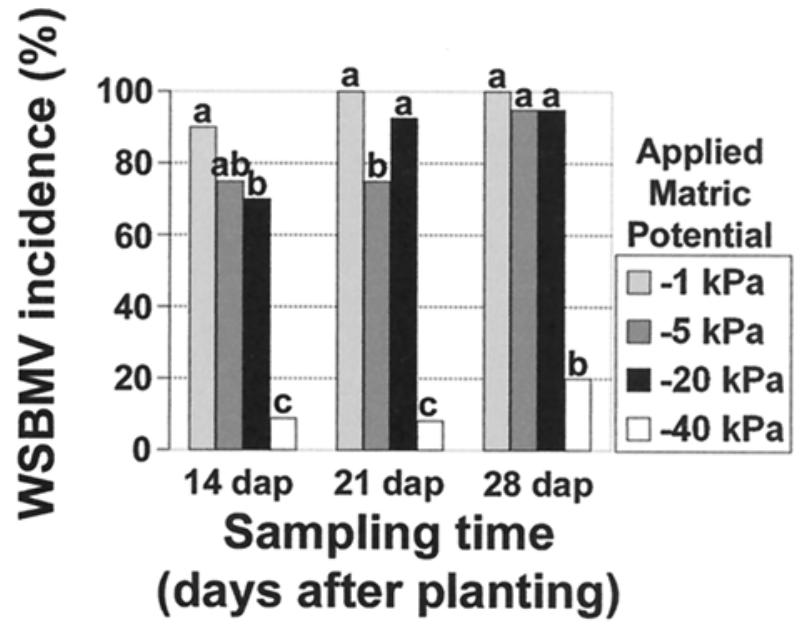

Fig. 4. Conduciveness to Wheat soilborne mosaic virus (WSBMV) transmission as affected by soil matric potentials and time after planting. Bars with different letters within each sampling time are significantly different at $\alpha=0.05$.

TABLE 2. Analysis of maximum likelihood estimates (MLEs) for determining the time required for Wheat soilborne mosaic virus transmission, based on $6.5,10,15$, and $20^{\circ} \mathrm{C}^{\mathrm{a}}$

\begin{tabular}{lcccrr}
\hline Parameter & df & MLE & SE & Wald $\chi^{2 b}$ & $P$ value \\
\hline Intercept & 1 & -1.0927 & 1.0176 & 1.1532 & 0.2829 \\
Hours $^{\mathrm{c}}$ & 1 & -0.1019 & 0.0261 & 15.2729 & $<0.0001$ \\
Temperature $^{\mathrm{d}}$ & 1 & -0.1805 & 0.1686 & 1.1461 & 0.2844 \\
Temperature $^{2 \mathrm{e}}$ & 1 & 0.00708 & 0.00615 & 1.3282 & 0.2491 \\
Hours-temperature $^{2}$ & 1 & 0.0199 & 0.00434 & 21.1550 & $<0.0001$ \\
Hours-temperature $^{2}$ & 1 & -0.00064 & 0.000158 & 16.2554 & $<0.0001$ \\
\hline
\end{tabular}

a This table is derived from the output of Proc Logistic in SAS (SAS Institute, Cary, NC) with both hours and temperature as random variables.

b The Wald chi-square test statistic is a likelihood-ratio statistic of the null hypothesis that the parameter for the given predictor is zero. This has an asymptotic $\chi^{2}$ distribution.

${ }^{c}$ Duration in the conducive matric potential treatment.

d Temperature (degrees Celsius) maintained for conducive matric potential treatment.

e Temperature squared. perature during conducive moisture treatment and the duration of the conducive moisture treatment were highly significant predictors of WSBMV transmission (Table 2). The model presented in Table 2 predicts an optimum temperature for WSBMV transmission near $15^{\circ} \mathrm{C}$, reflected by temperature as a second-order polynomial. Furthermore, the response of transmission to the duration of the conducive moisture treatment depends on temperature because hours and temperature interact.

As a negative control for comparison, a subset of cores was held for 48 or $96 \mathrm{~h}$ at nonconducive soil matric potentials at each of the temperature treatments. A baseline transmission of 0 to $20 \%$ was observed at all temperatures in the negative control. Within the 96-h scope of the experiment, no significant transmission occurred at $6.5^{\circ} \mathrm{C}$ compared with the nonconducive negative control (i.e., the odds ratio was not significantly different from 1 at $\alpha=0.05$ [Fig. 5]).

Significantly more WSBMV transmission occurred at $15^{\circ} \mathrm{C}$ than at the other temperatures tested, with the odds of transmission remaining significantly greater than the pooled negative control at every time point from $24 \mathrm{~h}$ after introduction to a conducive soil matric potential $(\alpha=0.05)$. The odds for WSBMV transmission at $15^{\circ} \mathrm{C}$ after $96 \mathrm{~h}$ at a conducive soil matric potential were 106.4-fold greater than if a nonconducive soil matric potential had been maintained. Significant transmission occurred at $20^{\circ} \mathrm{C}$ at $36 \mathrm{~h}$ and thereafter $(\alpha=0.05)$. For $10^{\circ} \mathrm{C}$, significant transmission occurred at 24,48 , and $96 \mathrm{~h}$, but the 36 -h time point was not significantly different from the pooled negative control $(\alpha=0.05)$. Because of the overall trends at each temperature over time, it seems likely that the $10^{\circ} \mathrm{C} / 24$-h time point was significant due to a type I error (i.e., significant infection occurred when it was not expected), which could be anticipated considering the 24 comparisons made at $\alpha=0.05$. Overall, given equally conducive soil matric potential, the data suggest that $15^{\circ} \mathrm{C}$ is more conducive than $20^{\circ} \mathrm{C}$, which is more conducive than $10^{\circ} \mathrm{C}$, and $6.5^{\circ} \mathrm{C}$ is not conducive for WSBMV transmission.

Repeating this experiment at $6.5,8$, and $10^{\circ} \mathrm{C}$, we found similar trends although our transmission efficiency was somewhat reduced at all time points for both 6.5 and $10^{\circ} \mathrm{C}$ (Fig. 6). Once again, both the temperature during conducive moisture treatment and the duration of the conducive moisture treatment were highly significant predictors of WSBMV transmission (Table 3). No significant transmission occurred at $6.5^{\circ} \mathrm{C}$. We first detected significant transmission at $36 \mathrm{~h}$ for $10^{\circ} \mathrm{C}$ and at $96 \mathrm{~h}$ for $8^{\circ} \mathrm{C}$ (Fig. 6).

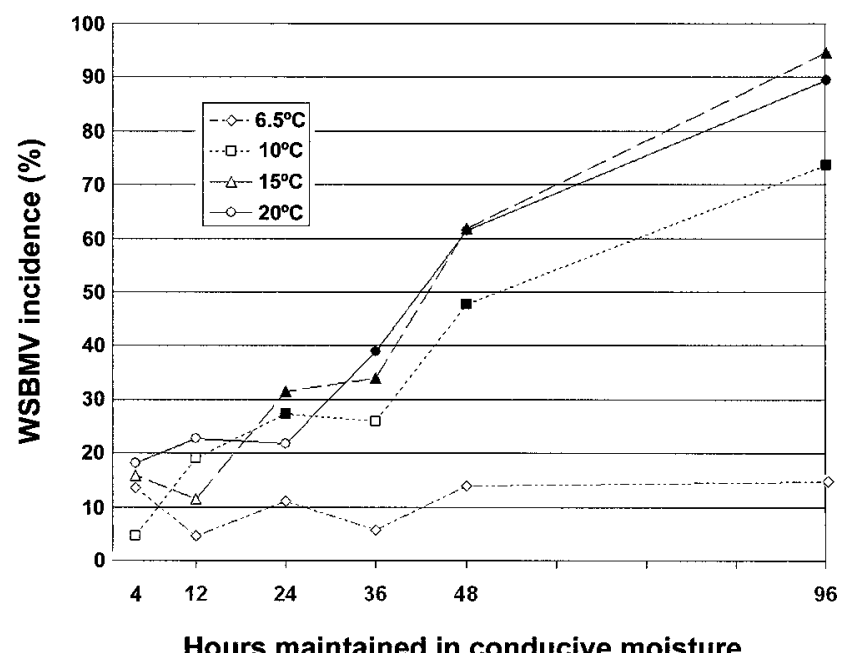

Fig. 5. Time required for Wheat soilborne mosaic virus (WSBMV) transmission at four temperatures given conducive matric potential. Filled symbols denote significantly greater odds of infection than the pooled negative control at $\alpha=0.05$. Open symbols are not significantly different from the pooled negative control at $\alpha=0.05$. 


\section{DISCUSSION}

In this paper, we describe the basis for increased or decreased WSBMV transmission by $P$. graminis from field soil using two environmental conditions, soil matric potential and temperature, in a growth chamber. We were able to consistently achieve transmission efficiencies of 90 to $100 \%$ after only $96 \mathrm{~h}$ under the most conducive conditions, which is in stark contrast to previous reports of 20 to $40 \%$ maximal transmission with field soil $(10,11$, 16). The higher transmission rates may have been the result of a more precise maintenance of soil environment conditions conducive to $P$. graminis zoospore movement, root infection, and virus inoculation and infection. Alternatively, the daily fluctuation of moisture could have triggered transmission events.

Zoospore size and motility may provide some insight into the reduced infection potential at $-40 \mathrm{kPa}$. The bodies of plasmodiophorid zoospores range in size from 3 to $6 \mu \mathrm{m}$ and the whiplash flagellum extends an additional $15 \mu \mathrm{m}(3,18)$. At the nonconducive matric potential of $-40 \mathrm{kPa}$, the largest pore filled with water has a diameter of $7.4 \mu \mathrm{m}$, whereas at the conducive matric potential of $-20 \mathrm{kPa}$, the largest pore filled with with water has a diameter of $14.7 \mu \mathrm{m}$. Thus, the average $P$. graminis zoospore should be able to move freely in water-filled pores at $-20 \mathrm{kPa}$ or wetter but may encounter barriers at $-40 \mathrm{kPa}$. The size of the largest filled pore is a function of matric potential, not soil type. Thus, this model would hold true for any location and soil type, given the same vector characteristics.

The results presented here vary slightly from a previous study that used hanging water columns with fritted filters, which suggested that the driest soil matric potential tested $(-20 \mathrm{kPa})$ was significantly less conducive to WSBMV transmission than was $-13 \mathrm{kPa}$ (11). The hanging water columns in that study were unable to keep pace with the water requirements of the wheat seedlings, resulting in final soil water contents that were significantly drier than the original treatments, perhaps contributing to that study's low transmission rates (6 to 20\%). Based on that study, we decided to establish the initial soil matric potential precisely and to maintain treatments through the duration of the study by hand watering the cores to equilibrium weight on a daily basis. Although some soil water was lost between watering, no individual core reached the soil matric potential of the next drier treatment.

Several studies have shown that plasmodiophorids in North America, including $P$. graminis, express optimal activity at or near

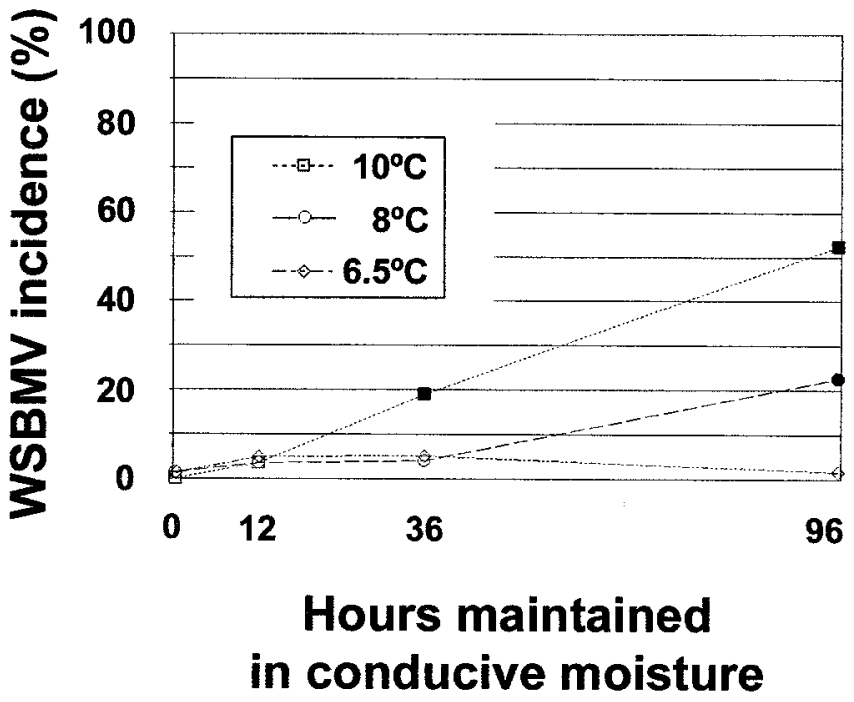

Fig. 6. Time required for Wheat soilborne mosaic virus (WSBMV) transmission between 6.5 to $10^{\circ} \mathrm{C}$ given conducive matric potential. Filled symbols denote significantly greater odds of infection than the pooled negative control at $\alpha=0.001$. Open symbols are not significantly different from the pooled negative control at $\alpha=0.1$. $15^{\circ} \mathrm{C}(15,16,202)$, and our results corroborate those findings. Coupled with data that zoospore suspensions at $15^{\circ} \mathrm{C}$ require $3 \mathrm{~h}$ for attachment and penetration to occur (2), our current study provides further insight into the timing of $P$. graminis infection events. The data suggest that more than $9 \mathrm{~h}$ are required for the combined events of (i) the production of a $P$. graminis germination signal by the host, (ii) its perception by $P$. graminis, (iii) germination from resting spore to zoospore, and (iv) the added impediments of locomotion through the soil matrix instead of a solution.

Our inability to detect WSSMV transmission using the same experimental design was unexpected. The soil was taken from a nursery in which WSSMV epidemics have occurred for the past 2 decades regardless of planting date in all but 1 year (7). A study by Slykhuis (22) showed that WSSMV transmission can occur within 16 days at temperatures ranging from 7.5 to $17.5^{\circ} \mathrm{C}$. This cooler upper limit on WSSMV transmission compared with WSBMV transmission could reflect the lower temperatures required for WSSMV replication. But in our study, we were unable to detect WSSMV transmission, even with 4 and $12^{\circ} \mathrm{C}$ incubation periods for viral replication. In our nursery, we are currently testing the hypothesis that an alternate vector with different environmental requirements is involved in WSSMV transmission. This alternate vector could be a different biotype of $P$. graminis or perhaps a different organism. Another hypothesis is that WSSMV is unable to establish infection at $15^{\circ} \mathrm{C}$.

Based on the Slykhuis (22) study and the results of our study, we suggest a model in which each zoospore infection event is associated with some odds of virus transmission and systemic movement. Therefore, on average, multiple root infections in autumn are required for symptom production in the following spring. Although dry soils are not conducive for the vector to swim to the plant, the root itself may grow to one or several zoospores, thereby triggering infection. The two studies suggest that rare events such as these are productive enough to be detected by ELISA in roots but seldom by symptoms in leaves. Even conducive conditions, for which significant transmissions may be detected in roots within $24 \mathrm{~h}$, may be required for multiple days in order to reach a threshold for eventual foliar symptom expression in a plant.

The air pressure cell apparatus described and used in this paper provides a novel means of precisely establishing and maintaining soil matric potential for applications in the epidemiology of soilborne pathogens. Beyond the applications described here, air pressure cells could be used in standardized screens to monitor the effect of mutations on pathogen virulence when inoculated into sterile soil culture, the effect of pesticides on soil microfauna, or the effect of cultural practices, such as rotation, on inoculum density.

TABLE 3. Analysis of maximum likelihood estimates (MLEs) for determining the time required for Wheat soilborne mosaic virus transmission, based on $6.5,8$, and $10^{\circ} \mathrm{C}^{\mathrm{a}}$

\begin{tabular}{lrccrr}
\hline Parameter & df & MLE & SE & Wald $\chi^{2 \mathrm{~b}}$ & $P$ value \\
\hline Intercept & 1 & -2.5276 & 0.9500 & 7.0782 & 0.0078 \\
Hours $^{\mathrm{c}}$ & 1 & -0.1109 & 0.0212 & 27.2663 & $<0.0001$ \\
Temperature $^{\mathrm{d}}$ & 1 & -0.0475 & 0.1582 & 0.0900 & 0.7641 \\
Temperature $^{2 \mathrm{e}}$ & 1 & 0.00414 & 0.00580 & 0.5098 & 0.4752 \\
Hours-temperature $^{2}$ & 1 & 0.0211 & 0.00356 & 35.3267 & $<0.0001$ \\
Hours-temperature $^{2}$ & 1 & -0.00068 & 0.000131 & 26.6514 & $<0.0001$ \\
\hline
\end{tabular}

a This table is derived from the output of Proc Logistic in SAS (SAS Institute, Cary, $\mathrm{NC}$ ) with both hours and temperature as random variables.

${ }^{b}$ The Wald chi-square test statistic is a likelihood-ratio statistic of the null hypothesis that the parameter for the given predictor is zero. This has an asymptotic $\chi^{2}$ distribution.

${ }^{\mathrm{c}}$ Duration in the conducive matric potential treatment.

${ }^{\mathrm{d}}$ Temperature (degrees Celsius) maintained for conducive matric potential treatment.

e Temperature squared. 


\section{ACKNOWLEDGMENTS}

This research was supported by Cornell University Hatch Project NYC153472 and a graduate research assistantship to L. Cadle-Davidson from the Department of Plant Pathology, Cornell University, Ithaca, NY.

\section{LITERATURE CITED}

1. Adams, M. J. 1990. Epidemiology of fungally-transmitted viruses. Soil Use Manag. 6:184-189.

2. Adams, M. J., and Swaby, A. G. 1988. Factors affecting the production and motility of zoospores of Polymyxa graminis and their transmission of Barley yellow mosaic virus (BaYMV). Ann. Appl. Biol. 112:69-78.

3. Aist, J. R., and Williams, P. H. 1971. The cytology and kinetics of cabbage root hair penetration by Plasmodiophora brassicae. Can. J. Bot. 49:2023-2034.

4. Brakke, M. K. 1971. Soilborne wheat mosaic virus. No. 77 in: Descriptions of Plant Viruses. Commonw. Mycol. Inst./Assoc. Appl. Biol., Kew, England.

5. Brakke, M. K., Estes, A. P., and Schuster, M. L. 1965. Transmission of Soilborne wheat mosaic virus. Phytopathology 55:79-86.

6. Campbell, R. N. 1996. Fungal transmission of plant viruses. Annu. Rev. Phytopathol. 34:87-108.

7. Carroll, J. E., Bergstrom, G. C., and Gray, S. M. 1997. Dynamics of Wheat spindle streak mosaic Bymovirus in winter wheat. Eur. J. Plant Pathol. 103:313-321.

8. Carroll, J. E., Gray, S. M., and Bergstrom, G. C. 1995. Use of antiserum to a New York isolate of Wheat spindle streak mosaic virus to detect related Bymoviruses from North America, Europe, and Asia. Plant Dis. 79:346-353.

9. Cunfer, B. M., Demski, J. W., and Bays, D. C. 1988. Reduction in plant development, yield, and grain quality associated with Wheat spindle streak mosaic virus. Phytopathology 78:198-204.

10. Driskel, B. A., Hunger, R. M., Payton, M. E., and Verchot-Lubicz, J. 2002. Response of hard red winter wheat to Soilborne wheat mosaic virus using novel inoculation methods. Phytopathology 92:347-354.
11. Himmel, P. T., Simmons, F. W., Hewings, A. D., and Glawe, D. A. 1992. Effects of soil-water status on infection of soft red winter wheat by Soilborne wheat mosaic-virus. Can. J. Plant Pathol. 14:147-151.

12. Hunger, R. M., Armitage, C. R., and Sherwood, J. L. 1989. Effects of Wheat soilborne mosaic virus on hard red winter wheat. Plant Dis. 73:949-952.

13. Karunatilake, U. P., and van Es, H. M. 2002. Rainfall and tillage effects on soil structure after alfalfa conversion to maize on a clay loam soil in New York. Soil Tillage Res. 67:135-146.

14. Klute, A. 1986. Water retention: Laboratory methods. 635-662 in: Methods of Soil Analysis, Part 1. Agronomy 9. A. Klute, ed. Am. Soc. Agron./Soil Sci. Soc. Am., Madison, WI.

15. Ledingham, G. A. 1939. Studies on Polymyxa graminis n. Gen. n. sp., a Plasmodiophoraceous root parasite of wheat. Can. J. Res. 17:38-51.

16. Legreve, A., Delfosse, P., Vanpee, B., Goffin, A., and Maraite, H. 1998. Differences in temperature requirements between Polymyxa sp. of Indian origin and Polymyxa graminis and Polymyxa betae from temperate areas. Eur. J. Plant Pathol. 104:195-205.

17. Littlefield, L. J., Whallon, J. H., Doss, P. J., and Hassan, Z. H. 1998. Postinfection development of Polymyxa graminis in roots of Triticum aestivum. Mycologia 90:869-882.

18. Merz, U. 1997. Microscopical observations of the primary zoospores of Spongospora subterranea f. sp. subterranea. Plant Pathol. 46:670-674.

19. Miller, N. R., Bergstrom, G. C., and Sorrells, M. E. 1992. Effect of Wheat spindle streak mosaic virus on yield of winter wheat in New York. Phytopathology 82:852-857.

20. Ramsey, G. B. 1918. Influence of moisture and temperature upon infection by Spongospora subterranea. Phytopathology 8:29-31.

21. Slykhuis, J. T. 1970. Factors determining the development of Wheat spindle streak mosaic caused by a soilborne virus in Ontario. Phytopathology 60:319-331.

22. Slykhuis, J. T. 1974. Differentiation of transmission and incubation temperatures for Wheat spindle streak mosaic virus. Phytopathology 64:554-557.

23. Tomlinson, J. A. 1956. Control of watercress crook root disease by zincfritted glass. Nature 178:1301-1302. 